\title{
Clinical Significance of Upper Airway Virus Detection in Critically Ill Hematology Patients
}

Jérôme Legoff ${ }^{1 *}$, Noémie Zucman ${ }^{2 *}$, Virginie Lemiale ${ }^{2}$, Djamel Mokart ${ }^{3}$, Frédéric Pène ${ }^{4}$, Jérôme Lambert $^{5}$, Achille Kouatchet ${ }^{6}$, Alexandre Demoule ${ }^{7}$, François Vincent ${ }^{8}$, Martine Nyunga ${ }^{9}$, Fabrice Bruneel $^{10}$, Adrien Contejean ${ }^{2}$, Séverine Mercier-Delarue ${ }^{1}$, Antoine Rabbat ${ }^{4}$, Christine Lebert $^{11}$, Pierre Perez $^{12}$, Anne-Pascale Meert ${ }^{13}$, Dominique Benoit ${ }^{14}$, Carole Schwebel ${ }^{15}$, Mercé Jourdain ${ }^{16}$, Michael Darmon $^{2}$, Matthieu Resche-Rigon ${ }^{5}$, Elie Azoulay ${ }^{2}$

* Jérôme LeGoff and Noémie Zucman contributed equally to this work.

${ }^{1}$ AP-HP, Virology Department, Saint Louis Teaching Hospital, Paris, FRANCE

${ }^{2}$ AP-HP, ICU, Saint Louis Teaching Hospital, Paris, FRANCE

${ }^{3}$ ICU, Paoli Calmette Institute, Marseille, FRANCE

${ }^{4}$ AP-HP, ICU, Cochin Teaching Hospital, Paris, France

${ }^{5}$ AP-HP, Statistics Department, Saint Louis Teaching Hospital, Paris, FRANCE

${ }^{6} \mathrm{ICU}$, Angers Teaching Hospital, Angers, FRANCE

${ }^{7}$ AP-HP, ICU, Pitié Salpêtrière Teaching Hospital, Paris, FRANCE

${ }^{8}$ AP-HP, ICU Avicennes Teaching Hospital, Bobigny, FRANCE

${ }^{9}$ ICU, Roubaix Regional Hospital Center, Roubaix, FRANCE

${ }^{10}$ ICU, Versailles Teaching Hospital, Le Chesnay, FRANCE

${ }^{11}$ ICU, District Hospital Center, La Roche sur Yon, FRANCE

${ }^{12}$ ICU, Brabois Teaching Hospital, Nancy, FRANCE

${ }^{13}$ ICU, Jules Bordet Institute, Brussels, BELGIUM

${ }^{14}$ ICU, Ghent University Hospital, Ghent, BELGIUM

${ }^{15}$ ICU, Grenoble Teaching Hospital, Grenoble, FRANCE

${ }^{16}$ ICU, Regional Teaching Hospital, Lille, FRANCE

Corresponding author: Professor Elie Azoulay, Medical Intensive Care Unit, APHP, Hôpital Saint-Louis, Famirea Study Group. ECSTRA team, and clinical epidemiology, UMR 1153 (Center of Epidemiology and Biostatistics Sorbonne Paris Cité, CRESS), INSERM, Paris Diderot Sorbonne University. E-mail: elie.azoulay@sls.aphp.fr 


\section{Contributions of each author}

All authors substantially contributed to the conception and design of the work, as well as to the acquisition, analysis, and interpretation of data. All have worked on, revised and approved the submitted manuscripts. EA is the guarantor of the study, had full access to all the data, and takes responsibility for the integrity of the data and the accuracy of the data analysis.

\section{Sources of support}

The study was funded by grant \#PHRC AOM 08235 from the French Ministry of Health and French Intensive Care Society (FICS). MSD AVENIR has supported Saint-Louis hospital and the support was used to pay technicians and statisticians. GenMark Dx ${ }^{\circledR}$, Carlsbad, CA,

donated all ePlex ${ }^{\circledR}$ Respiratory Pathogen Panels and MSD had no role in designing, conducting, or interpreting the study or in writing the article.

Running head: Virus Detection in ICU Hematology Patients

Descriptor number: 4.5, Diagnostic techniques and monitoring

Word count: 3009 


\section{At a glance commentary}

\section{Scientific knowledge on the subject}

In critically ill hematology patients, identifying the cause of the acute illness while providing life-supporting interventions is the cornerstone of the initial management. PCR panels for the rapid detection of viruses are now available. However, the clinical significance of positive PCR results on upper respiratory tract samples remains unclear.

\section{What this study adds to the field}

Among critically ill hematology patients, one in six overall and one in four with acute respiratory failure (ARF) had a virus identified in a nasal swab at ICU admission. Presence of a virus was associated with lymphoproliferative disorders, hematopoietic stem cell transplantation, and treatment with steroids or other immunosuppressants. The most common viruses were rhinovirus/enterovirus (56.4\%) and influenza/parainfluenza (PIV)/respiratory syncytial viruses (RSV) (30.7\%). Virus detection was associated with higher ICU mortality, and this association was strongest for influenza/PIV/RSV. In patients with ARF, detection of any respiratory virus independently predicted ICU mortality. 


\section{Abbreviations}

95\% CI, 95\% confidence interval

$\mathrm{ARF}$, acute respiratory failure

CT, computed tomography

Grrr-OH, Groupe de recherche respiratoire en réanimation en Onco-Hématologie, a task force working on critical respiratory diseases in patients with cancer or hematological malignancies

$\mathrm{HM}$, hematological malignancies

hMPV, human metapneumovirus

HSCT, hematopoietic stem-cell transplant

ICU, intensive care unit

IPA, invasive pulmonary aspergillosis

OR, odds ratio

PCR, polymerase chain reaction

PIV, parainfluenza virus

RRT, renal replacement therapy

RSV, respiratory syncytial virus

SOFA, Sequential Organ Failure Assessment 


\begin{abstract}
Rationale: Noninvasive diagnostic multiplex molecular tests may enable the early identification and treatment of viral infections in critically ill immunocompromised patients.

Objectives: To assess the association between viral detection in nasopharyngeal swabs and ICU mortality in critically ill hematology patients.

Methods: Post-hoc analysis of a prospective cohort of critically ill hematology patients admitted to 17 ICUs. Nasal swabs sampled and frozen at ICU admission were tested using a multiplex PCR assay. Predictors of ICU mortality and assay positivity were identified.
\end{abstract}

Measurements and Main Results: Of the 747 patients (447 with acute respiratory failure [ARF]), 21.3\% had a virus detected (56.4\% rhinovirus/enterovirus and 30.7\% influenza/parainfluenza [PIV]/respiratory syncytial viruses [RSV]). Overall ICU and hospital mortality rates were $26 \%$ and $37 \%$, respectively. Assay positivity was associated with lymphoproliferative disorders, hematopoietic stem cell transplantation, treatment with steroids or other immunosuppressants, ARF (25.5\% vs. $16.3 \%, P=0.004)$, and death in the ICU $(28.9 \%$ vs. $19.3 \%, P=0.008)$. The association with ICU mortality was significant for all viruses and was strongest for influenza/PIV/RSV. In patients with ARF, detection of any respiratory virus was independently associated with ICU mortality (odds ratio, 2.07; 95\% confidence interval, 1.22-3.50).

Conclusions: Respiratory virus detection in the upper airway by multiplex PCR assay is common in critically ill hematology patients. In patients with ARF, respiratory virus detection was independently associated with ICU mortality. Multiplex PCR assay may prove helpful for the risk stratification of hematology patients with ARF. Studies to understand whether respiratory tract viruses play a causal role in outcomes are warranted.

Abstract word count: 248

Keywords: Bone marrow transplantation, neutropenia, oxygen, influenza, parainfluenza virus, respiratory syncytial virus, mechanical ventilation, multiplex PCR 


\section{INTRODUCTION}

Among patients with hematological malignancies (HM), up to $40 \%$ experience acute respiratory failure (ARF), for which the risk factors include prolonged neutropenia, complex immune deficiencies, and drug-related pulmonary toxicity (1-5). The causes of lung disease vary with the nature of underlying malignancy, level of immunosuppression, and treatment intensity. Early identification of the cause of ARF is associated with improved outcomes (68). Current diagnostic strategies combine semi-invasive tests (fiberoptic bronchoscopy with bronchoalveolar lavage $[\mathrm{BAL}]$, minimally invasive computed tomography $[\mathrm{CT}]$-guided biopsies) with noninvasive PCR assays on sputum, nasopharyngeal aspirates, and nasal swabs. This combined strategy can be expected to identify the cause in about $80 \%$ of patients (9-11). Hospital mortality, which can reach 50\%, is highest when the cause of ARF remains unknown $(8,12-14)$.

Whereas up to $40 \%$ of patients with hematological malignancies have one or more viruses detected in their respiratory samples, viruses, mainly diagnosed with the collection of upper respiratory tract samples, are much less considered than other pathogens such bacteria or Aspergillus as likely cause of ARF (12-15). A positive virus PCR test on nasopharyngeal aspirates or nasal swabs may reflect either upper or lower respiratory tract infection, the clinical consequences of which can differ substantially. However, a positive test may also indicate asymptomatic carriage, perhaps with an increased viral burden due to worsening immunosuppression, and with or without an impact on mucosal function and/or the local flora. When the virus is clinically relevant, as seen during H1N1 epidemics, its rapid detection can help to identify patients at risk for respiratory deterioration, determine that isolation and preventive measures are needed, and guide early antiviral therapy $(19,20)$. 
Multiplex assays on bronchoalveolar lavage fluid or nasal secretions are effective in detecting a wide range of pathogens (21-23), including several viruses known to cause pneumonia (e.g., influenza virus, respiratory syncytial virus, parainfluenza virus, human metapneumovirus) and others whose potential for causing lower respiratory tract disease is unclear (e.g., rhinovirus, coronavirus) $(24,25)$. Thus, whether the detection of viruses in respiratory samples has diagnostic, therapeutic, and/or prognostic relevance is unclear.

The objective of this study was to assess the clinical relevance of a positive PCR assay for viruses on respiratory samples of critically ill hematology patients with or without ARF. We retrospectively assessed prospectively collected nasal swabs using a multiplex assay and compared patients with and without positive results, notably regarding the presence of ARF and ICU mortality. 


\section{PATIENTS AND METHODS}

\section{Patients}

We performed a post-hoc analysis of data from a prospective multicenter cohort study of 1011 critically ill patients with HM admitted to 17 ICUs between January, 1, 2010, to May, 1, 2011(14). The study was approved by the appropriate ethics committees. All patients/relatives gave written informed consent to study participation.

\section{Data collection}

In each center, an investigator used a standardized electronic case-report form to prospectively collect the study data. The Sequential Organ Failure Assessment (SOFA) score was computed at admission. ARF was defined as oxygen saturation $<90 \%$ or $\mathrm{PaO}_{2}<60$ $\mathrm{mmHg}$ on room air combined with a respiratory rate $>30 / \mathrm{min}$ and/or clinical signs of respiratory distress $(14,26)$. A comprehensive diagnostic assessment was performed including a physical examination and CT followed by bronchoscopy and BAL and/or noninvasive diagnostic tests $(27,11)$. Etiological diagnoses were made by consensus among the managing physicians (intensivists, hematologists, and consultants). Patients with ARF were classified into four diagnostic categories (8) (infectious pneumonia as defined by a clinically or microbiologically documented lower respiratory tract infection; non-infectious lung involvement; opportunistic infection; and undetermined diagnosis).

\section{Molecular assay for respiratory virus detection}

Nasopharyngeal flocked swabs were collected at admission in $3 \mathrm{~mL}$ of Universal Transport Medium (UTM) (Copan Diagnostics Inc, Murrieta, CA) in patients admitted on weekdays and stored at $-80^{\circ} \mathrm{C}$ until testing. For the present study, a multiplex molecular assay (ePlex ${ }^{\circledR}$ Respiratory Pathogen Panel, GenMark Diagnostics Inc., Carlsbad, CA) was performed according to the manufacturer's instructions. This assay tests for 20 respiratory 
viruses (influenza viruses A-H1, A-H1N1, A-H3, and B; respiratory syncytial viruses [RSV] A and B; parainfluenza viruses [PIV] types 1, 2, 3, and 4; human metapneumovirus [hMPV]; rhinovirus and/or enterovirus; coronaviruses 229E, HKU1, NL63, OC43, and MERS; adenovirus, and bocavirus) and for four bacteria (Bordetella pertussis, Chlamydophila pneumoniae, Legionella pneumophila, and Mycoplasma pneumoniae).

Samples positive for rhinovirus/enterovirus, underwent sequencing the VP4/VP2 coding region as previously described (28). PCR products were sequenced on an ABI 3100 DNA Sequencer (Applied Biosystems, Life Technologies, Carlsbad, CA). Alignment and sequence comparison to NCBI published sequences were carried out using the Geneious 8.0.5 software (Biomatters, Auckland, NZ) and MEGA version 7 (CEMI, Tempe, AZ).

\section{Statistical analysis}

The primary outcome was the rate of respiratory viral infections in patients with ARF and those without. Secondary outcomes were the association between respiratory viral infections and death in ICU and risk factors of death in patients with ARF. Several groups were compared: patients with respiratory viral infections and those without, patients with and without ARF. ePlex ${ }^{\circledR}$ positive status was defined as the detection of at least one pathogen by the ePlex ${ }^{\circledR}$ respiratory panel

Categorical variables were described as numbers and percentages and quantitative variables as medians $\left(25^{\text {th }}-75^{\text {th }}\right.$ quartiles $)$. Between-group comparisons were with Fisher's exact test for categorical variables and the Wilcoxon rank sum test for quantitative variables.

Factors associated with ICU mortality were assessed by logistic regression. In addition to the $\mathrm{ePlex}^{\circledR}$ assay result, the model included both the variables associated with the outcome in the original study (14) and the clinically meaningful variables (underlying malignancy, poor ECOG performance status, Charlson comorbidity index, allogeneic 
hematopoietic stem cell transplant [HSCT] recipient, complete or partial remission, time from hospital to ICU admission $<24 \mathrm{~h}$, SOFA score, organ infiltration by the malignancy, and invasive pulmonary aspergillosis). Variable selection was with a backward stepwise procedure with a stopping rule based on the Akaike criterion. Odds ratios (ORs) of variable effects in the final model are reported with their 95\% confidence intervals (95\%CIs). Goodness-of-fit of the final model was checked using the le Cessie-van Houwelingen test. All tests were two-sided at the 0.05 level. Analyses were performed using the R statistical package (http://www.R-project.org). 


\section{RESULTS}

\section{Patients}

Among the 1011 critically ill hematology patients, 747 had nasal swabs tested by ePlex $^{\circledR}$ (Figure 1). None of the collected variables were significantly different between the 747 included patients and the 264 patients without nasal swabs.

Table 1 reports the patient characteristics at admission. Median age was 60 [49;70] years. Almost half the patients had a lymphoid malignancy and one-third had myeloid malignancies (Table 1). The HM was newly diagnosed in $280(37.5 \%)$ patients and in partial or complete remission in 174 (23.3\%) patients. There were 190 (25.4\%) HSCT recipients. In the previous month, $423(56.6 \%)$ patients had received corticosteroids or other immunosuppressants. The main reason for ICU admission was ARF ( $\mathrm{n}=447,59.8 \%)$. Shock was present in $316(42.4 \%)$ patients. Invasive mechanical ventilation was provided to 351 (33.6\%) patients and vasoactive drugs to $370(49.5 \%)$ patients. ICU and hospital mortality rates were $26 \%$ and $37.1 \%$, respectively.

\section{Results of molecular viral detection}

The ePlex ${ }^{\circledR}$ Respiratory Pathogen Panel identified 179 pathogens in $163(21.8 \%)$ patients, including $149(83.2 \%)$ with a single pathogen and 14 with more than one pathogen (12 with two and 2 with three pathogens). Four samples were positive for Legionella pneumophila. All other samples were positive for respiratory viruses (Table 2).

The most prevalent virus was rhinovirus/enterovirus ( $n=92 / 163,56.4 \%)$, followed by coronavirus $(n=22,13.5 \%)$, influenza virus $(n=20,12.3 \%)$, RSV $(n=18,11.0 \%)$, and PIV $(n=12,7.4 \%)$. Adenovirus $(n=5,3.1 \%), \operatorname{hMPV}(n=4,2.5 \%)$, and bocavirus $(n=2,1.2 \%)$ were less frequently detected. The virus type was determined for 71 of the 92 
rhinovirus/enterovirus-positive samples, with the following results: rhinovirus species A, $\mathrm{n}=35$; rhinovirus species $\mathrm{B}, \mathrm{n}=9$; rhinovirus species $\mathrm{C}, \mathrm{n}=24$; and enterovirus $\mathrm{D} 68, \mathrm{n}=3$. Of the respiratory viruses, $66.8 \%$ were detected during the winter and spring. There was a seasonal variation of samples positive for respiratory viruses (Table 3). Influenza and RSV were significantly more detected during winter $(\mathrm{p}<0.0001)$ while rhinoviruses were slightly more frequent during summer and autumn $(\mathrm{p}=0.02)$ (Table $\mathrm{S} 1)$.

Overall, respiratory viruses were more frequently detected in patients with ARF (25.5\% vs. $16.3 \%, P=0.004)$ and in patients who died in the ICU ( $28.9 \%$ vs. $19.3 \%$, $P=0.008$ ) (Table 2). Influenza-like viruses (influenza/PIV/RSV) were particularly prevalent in patients with ARF $(10.1 \%$ vs. $1.7 \%, P<0.0001)$ and in patients who died in the ICU (11.3\% vs $5.1 \%, P=0.004)$. Rhinovirus/enterovirus, coronavirus, adenovirus, hMPV, and bocavirus were found in similar proportions of patients across subgroups with vs. without ARF and in ICU survivors vs. nonsurvivors. Viral-viral or viral-bacterial coinfections were not associated with ARF but were more prevalent in patients who died in the ICU (5.7 vs. $0.5 \%, P<0.0001)$.

\section{Characteristics and outcomes of patients with a positive viral assay}

As shown in Table 3, neither SOFA score on day 1 nor presence of shock differed between patients with vs. without detected viruses. Respiratory viruses were more frequently detected in HSCT recipients than in other patients $(42.9 \%$ vs. $20.7 \%, P<0.0001)$ and in patients on steroids $(46 \%$ vs. $36 \%, P=0.026)$ or other immunosuppressants $(23.0 \%$ vs. $16.6 \%, P=0.043$ ). Presence of respiratory symptoms on day 1 (including fever, cough, dyspnea, chest pain, wheezing, rhinitis, and/or myalgia) with or without signs of ARF was significantly more common in patients with a positive ePlex ${ }^{\circledR}(85.9 \%$ vs. $72.2 \%, P=0.0005)$. However, $23(14.1 \%)$ patients with a positive $\mathrm{ePlex}^{\circledR}$ had no respiratory symptoms on day 1 
but none had any Influenza-like virus (Table S2). In patients with no respiratory symptoms, there was no difference of mortality in ICU between patients with a positive ePlex ${ }^{\circledR}$ result and those with a negative ePlex ${ }^{\circledR}$ result (Table S3).

Overall there was no difference in of the presence of rhinovirus in patients who died in ICU compare to those who were discharged alive (Table 2). However, death was observed more frequently in patients with a detection of rhinovirus Species C $(11 / 24,45.8 \%)$ than in those with a detection of rhinovirus Species A or B (9/44, in 20.5\%) (Fisher exact test, p.value $=0.049)$ (Table 2). In addition, within the cohort of patients with ARF (447 patients), we observed a higher proportion of death among patients with Rhinovirus species C (9/17, $52.9 \%$ ) than among patients with Rhinovirus Species A or B (p.value=0.049).

Noninvasive ventilation was used significantly more often in virus-positive patients (39.9\% vs. $29.6 \%, P=0.017)$. For invasive mechanical ventilation, the difference was nearly significant $(54.0 \%$ vs. $45.0 \%, P=0.053)$. ICU mortality was higher in virus-positive patients (34.3\% vs. $23.6 \%, P=0.008)$. No significant difference was found for hospital mortality ( $41.1 \%$ vs. $36 \%, P=0.27)$ or mortality on day $90(47.7 \%$ vs. $45.2 \%, P=0.69)$. There were no differences in the use of vasoactive drugs or renal replacement therapy (RRT) or in the rate of ICU-acquired infections (Table 3).

\section{Characteristics and outcomes associated with respiratory virus detection in patients with acute respiratory failure (ARF)}

In the group with ARF (Table 4), the clinical presentation at admission was similar in the virus-positive and virus-negative patients. Although there was no difference in maximal oxygen flow in patients breathing spontaneously, the $\mathrm{PaO}_{2} / \mathrm{FiO}_{2}$ ratio tended to be lower in the virus-positive patients who required mechanical ventilation (118 [71-206] vs. 150 [96258], $P=0.052)$. 
The chest radiograph was more often normal in the virus-positive patients $(17.9 \%$ vs. $9.9 \%, P=0.039)$. In patients who underwent $\mathrm{CT}$ of the chest, the only finding that differed between groups was pleural effusion, which was significantly less common in the viruspositive group (12.3\% vs. $24.8 \%, P=0.009)$.

Among virus-positive patients with ARF, 27.2\% had clinically or microbiologically documented bacterial pneumonia. Documented bacterial pneumonia was less common among virus-positive than virus-negative patients. Invasive pulmonary aspergillosis (IPA) was diagnosed in $9.7 \%$ of virus-positive and $3.9 \%$ of virus-negative patients (Table 4 ).

The use of antibiotics and of life-supporting interventions (mechanical ventilation, vasoactive drugs, RRT) in the group with ARF was not significantly different between viruspositive and virus-negative patients. As in the overall population, a positive viral assay was associated with higher ICU mortality in the ARF group (40.3\% vs. $24.3 \%, \mathrm{P}=0.002)$. The hospital and day-90 mortality rates were not different between the virus-positive and virusnegative groups. Changes in the daily SOFA score from admission to day 7 were not different between virus-positive and virus-negative patients (Figure S1) and or patients with vs. without detection of influenza-like viruses (Figure S1).

By multivariable analysis, detection of a virus was independently associated with ICU mortality (OR, 2.07; 95\%CI, 1.22-3.50, $P=0.006)$. Other independent risk factors for ICU mortality were IPA (OR, 2.43; 95\%CI, 1.23-4.81; $P=0.01)$, poor ECOG performance status $(\mathrm{OR}, 1.89 ; 95 \% \mathrm{CI}, 1.09-3.27 ; P=0.024)$, and SOFA score $>7$ at admission $(\mathrm{OR}, 1.27$; 95\%CI, 1.20-1.36; $P<0.001$ ) (Figure 2, Table S4). Steroid therapy was not associated with a worse prognosis in patients with ARF (Table S5 and S6).

\section{Impact of influenza-like viruses}


In the overall population, patients with influenza-like viruses had higher ICU mortality (44.4\% vs. $24.5 \%, \mathrm{P}=0.002)$. They more often presented with ARF $(88.9 \%$ vs. $57.6 \%, \mathrm{P}<0.0001)$ and more often required invasive or noninvasive mechanical ventilation (75.9\% vs. 58.7\%, $\mathrm{P}=0.014)$ (Figure 3 ). 


\section{DISCUSSION}

In this study we assessed the clinical relevance of a positive multiplex PCR assay for viruses on respiratory samples of critically ill hematology patients. We analyzed nasopharyngeal swabs collected at admission to ICU in patients with or without respiratory symptoms, enabling to better estimate the clinical significance of detection of respiratory viruses. In this large multicenter prospective cohort study of 747 critically ill patients with HMs, respiratory virus detection was associated with both ARF and higher ICU mortality. Both associations were largely due to the influenza-like viruses (Influenza/PIV/RSV). Species $\mathrm{C}$ of rhinovirus was associated with a higher proportion of death among patients in the whole cohort and in patients with ARF than rhinovirus Species A or B.

Although there is no recommendation for routine molecular testing, multiplex PCR is widely used to identify the cause of ARF, in combination with clinical, radiological, and standard microbiological evaluations. However, due to the high sensitivity of molecular assays and high prevalence of asymptomatic carriage of respiratory viruses, a positive molecular assay is not proof that the detected virus is causing disease. Immunosuppression may increase the burden of viruses not conventionally associated with significant disease, so that a positive PCR assay may be merely a marker for poor immune function (29). In addition, presence of a virus can alter the bacterial flora in the upper respiratory tract, an effect that might in turn promote bacterial pneumonia (30). Finally, respiratory viruses may enhance bacterial adhesion to, and invasion of, the respiratory mucosa (30). In studies of patients with community-acquired bacterial pneumonia, viral coinfection was associated with a worse prognosis (31-33). Thus, the effects of respiratory viruses are complex, and whether virus detection by PCR in an upper airway sample from a critically ill hematology patient should lead to antiviral treatment is unclear. As a first step toward obtaining clarification, we routinely sampled the upper airway of unselected, critically ill, hematology 
patients at ICU admission, regardless of whether respiratory symptoms were present. The results were analyzed at a distance from ICU admission. Presence of a virus in this setting might indicate a direct contribution of the virus to the critical illness (e.g., viral pneumonia), an indirect contribution of the virus via alterations in respiratory tract ecology and mucosal function, asymptomatic carriage with no role for the virus in the symptoms but a possible viral load increase due to immunosuppression, or a false-positive test result. Antiviral treatment would be in order only in the first two cases. The lack of lower respiratory tract samples, such as broncho-alveolar lavages, hampered direct evaluation of the impact on respiratory tract ecology and mucosal function. We sought to determine whether any of our findings were in favor of a direct or indirect causal role for detected viruses in the clinical illness.

Half the pathogens detected in our patients were rhinovirus/enterovirus. With coronaviruses, rhinoviruses are the leading cause of rhinitis, and less often cause pneumonia $(29,34-38)$. The higher prevalence of these viruses than previously reported in hematology patients may be due to the very high sensitivity of ePlex ${ }^{\circledR}$, particularly for rhinovirus species C. Several studies have recently shown that rhinovirus could contribute to severe lower respiratory tract infections in immunocompromised hosts (39-41). Severe rhinovirus infections presented with similar clinical features and same overall mortality than Influenzalike viruses In our study including patients with or without respiratory symptoms at admission, the prevalence of rhinovirus did not differ neither between patients with ARF and those nor between who died in ICU or were alive at ICU discharge. Rhinovirus is classified into three species A, B and C. Some studies reported that species C was associated with more severe infections, with more frequent lower respiratory tract infections $(42,43)$ but some others found no difference between the three species $(41,44)$. In addition recent studies suggest that Species C targets specifically ciliated epithelial cells while species A and 
B may infect non epithelial cells (45). The analysis of rhinovirus as one group only may thus be not appropriate. In this series, we found that Species $\mathrm{C}$ was associated with a higher mortality in the whole cohort and in patients with ARF compare to species A and B. These results suggest that the impact of rhinovirus infection may differ according to the species. This observation needs to be confirmed in other studies and deserves further research to understand underlying mechanisms.

Other viruses were detected in similar proportions of patients after adjustment for age and season. In keeping with this fact, the higher frequencies of ARF and ICU death in the virus-positive group was largely ascribable to the patients with influenza-like viruses (Influenza/PIV/RSV, hMPV). Others have reported similar results (46).

Thus, in agreement with other studies, our results emphasize the need for specific antiviral therapy in critically ill patients with hematological malignancies when a molecular multiplex assay is positive for influenza in an upper respiratory tract sample Early oseltamivir therapy improves the outcome in critically ill patients with influenza: a propensity analysis (47-49).

Among patients with ARF, respiratory virus detection was a predictor of ICU mortality that was nearly as strong as IPA. While IPA is a well-known risk factor for mortality in critically ill hematology patients, our study is the first to report that respiratory viruses were also independently associated with ICU mortality. Three hypotheses may explain this association. One involves a double hit, in which patients developing a respiratory virus infection shortly before ICU admission would be then more vulnerable to bacterial infection, leading to a critical illness. The lower $\mathrm{PaO}_{2} / \mathrm{FiO}_{2}$ ratio in virus-positive patients may seem to support this possibility, but the more often normal chest radiographs and similar SOFA scores over the first week compared to virus-negative patients do not. Another hypothesis is that bacterial or fungal respiratory tract infection would promote viral 
infection via weakening of the local defense mechanisms (50). The viral infection may then worsen the initial disease. A recent work suggested that the alteration of microbial ecology after antibiotic exposure was associated with a higher risk of viral lower respiratory tract infection with following PIV, RSV, and hMPV (51). Viral infections and invasive fungal infections share common risk factors (52-54) that are common in hematology patients, such as allogeneic HSCT and treatment with corticosteroids or other immunosuppressants. Finally, a positive viral assay might be a marker for immunosuppression or other vulnerability factors.

The contribution of PCR assays to the etiological diagnosis of ARF is probably modest. Nevertheless, our results suggest that rapid routine multiplex molecular testing for upper respiratory tract viruses in hematology patients admitted to the ICU may contribute to identify patients at highest risk for mortality. Such finding could be delineated into different ways. Namely, based on a positive virus in the nasal swab, these high risk patients should be admitted earlier to the ICU/HDU to undergo noninvasive management and close monitoring. Moreover, these patients should be considered as more severely immunocompromised and may also be eligible for preventive strategies such as antifungal prophylaxis. However, for such practices to be implemented, we need to validate these concepts in future observational and interventional studies. Although antiviral drugs available to treat respiratory viral infections are currently limited to influenza, our results identify patients who should benefit to new antiviral drugs or included in trials evaluating treatments under development.

Regarding the association with IPA, antifungal treatment might be in order in patients with ARF who do not respond promptly to antibacterial treatment and whose multiplex test for upper respiratory tract viruses is positive. In patients whose test is positive for influenza, early antiviral treatment and preventive measures to limit nosocomial 
transmission may be warranted. Our results suggest that critically ill hematology patients may be a population of interest for evaluating new drugs targeting RSV and PIV.

This study has several limitations. For feasibility reasons, 264 patients $(26.1 \%$ of the initial cohort) admitted on weekends were not included. However, the baseline characteristics and ICU mortality of these 264 patients were not significantly different from those in the included patients. We had no information on the occurrence of hospital-acquired pneumonia or ventilator-associated pneumonia during the ICU stay. The study design does not allow conclusions about the nature of the link between the detection of viruses and ICU mortality. Indeed, although mortality related to infection is usually high in this setting, ascription of death to infection was not assessed due to the level of uncertainty. Future studies involving the collection of biomarkers and specific patient phenotypes in this hematology population are warranted. Also, lower respiratory tract samples and autopsy studies of the lung lesions might shed light on the role for viruses versus other causes of lung involvement, document undetected pathogens, and provide information on resident and recruited alveolar cells and their relationship to severity and mortality.

In conclusion, a respiratory virus was detected in the upper airway of one in six critically ill hematology patients overall and of one in four of those with ARF. Virus detection was more common in patients who died in the ICU, and this association was chiefly due to influenza/PIV/RSV. In patients with ARF, however, detection of any respiratory virus was an independent predictor of ICU mortality. Routine PCR screening of upper airway samples in critically ill hematology patients may help to identify patients at high risk for respiratory deterioration and mortality. However, whether these patients are potential candidates for immunomodulation, new antiviral treatments, early ICU admission, or antifungal therapy remains unclear. These results encourage a trial of routine screening for respiratory viral detection by PCR at ICU admission in hematology patients. Therapeutic 
indications must be appraised. This high-risk population may be a good target for evaluating the antiviral treatments that are currently being developed. 


\section{References}

1. Chaoui D, Legrand O, Roche N, Cornet M, Lefebvre A, Peffault de Latour R, Sanhes L, Huchon G, Marie J-P, Rabbat A. Incidence and prognostic value of respiratory events in acute leukemia. Leukemia 2004;18:670-675.

2. Azoulay E, Schlemmer B. Diagnostic strategy in cancer patients with acute respiratory failure. Intensive Care Med 2006;32:808-822.

3. Moreau A-S, Peyrony O, Lemiale V, Zafrani L, Azoulay E. Acute Respiratory Failure in Patients with Hematologic Malignancies. Clin Chest Med 2017;38:355-362.

4. Bird GT, Farquhar-Smith P, Wigmore T, Potter M, Gruber PC. Outcomes and prognostic factors in patients with haematological malignancy admitted to a specialist cancer intensive care unit: a 5 yr study. Br J Anaesth 2012;108:452-459.

5. Mokart D, van Craenenbroeck T, Lambert J, Textoris J, Brun J-P, Sannini A, ChowChine L, Hamouda S, Fouché L, Ettori F, Faucher M, Blache J-L. Prognosis of acute respiratory distress syndrome in neutropenic cancer patients. Eur Respir J 2012;40:169-176.

6. Rano A, Agusti C, Jimenez P, Angrill J, Benito N, Danes C, Gonzalez J, Rovira M, Pumarola T, Moreno A, others. Pulmonary infiltrates in non-HIV immunocompromised patients: a diagnostic approach using non-invasive and bronchoscopic procedures. Thorax 2001;56:379-387.

7. Azoulay É, Thiéry G, Chevret S, Moreau D, Darmon M, Bergeron A, Yang K, Meignin V, Ciroldi M, Le Gall J-R, Tazi A, Schlemmer B. The Prognosis of Acute Respiratory Failure in Critically Ill Cancer Patients: Medicine (Baltimore) 2004;83:360-370.

8. Contejean A, Lemiale V, Resche-Rigon M, Mokart D, Pène F, Kouatchet A, Mayaux J, Vincent F, Nyunga M, Bruneel F, Rabbat A, Perez P, Meert A-P, Benoit D, Hamidfar R, Darmon M, Jourdain M, Renault A, Schlemmer B, Azoulay E. Increased mortality in hematological malignancy patients with acute respiratory failure from undetermined 
etiology: a Groupe de Recherche en Réanimation Respiratoire en Onco-Hématologique (Grrr-OH) study. Ann Intensive Care 2016;6:102.

9. Rabbat A, Chaoui D, Lefebvre A, Roche N, Legrand O, Lorut C, Rio B, Marie J-P, Huchon G. Is BAL useful in patients with acute myeloid leukemia admitted in ICU for severe respiratory complications? Leukemia 2008;22:1361-1367.

10. Azoulay E, Mokart D, Rabbat A, Pene F, Kouatchet A, Bruneel F, Vincent F, Hamidfar R, Moreau D, Mohammedi I, Epinette G, Beduneau G, Castelain V, de Lassence A, Gruson D, Lemiale V, Renard B, Chevret S, Schlemmer B. Diagnostic bronchoscopy in hematology and oncology patients with acute respiratory failure: Prospective multicenter data*: Crit Care Med 2008;36:100-107.

11. Azoulay É, Mokart D, Lambert J, Lemiale V, Rabbat A, Kouatchet A, Vincent F, Gruson D, Bruneel F, Epinette-Branche G, Lafabrie A, Hamidfar-Roy R, Cracco C, Renard B, Tonnelier J-M, Blot F, Chevret S, Schlemmer B. Diagnostic Strategy for Hematology and Oncology Patients with Acute Respiratory Failure: Randomized Controlled Trial. Am J Respir Crit Care Med 2010;182:1038-1046.

12. Villa F, Coppadoro A, Bellani G, Foti G, Fumagalli R, Pesenti A. Etiology of respiratory failure is related to mortality in critically ill patients affected by a hematological malignancy: a retrospective study. Minerva Anestesiol 2010;76:7-12.

13. Burghi G, Lemiale V, Seguin A, Lambert J, Lacroix C, Canet E, Moreau A-S, Ribaud P, Schnell D, Mariotte E, Schlemmer B, Azoulay E. Outcomes of mechanically ventilated hematology patients with invasive pulmonary aspergillosis. Intensive Care Med 2011;37:1605-1612.

14. Azoulay E, Mokart D, Pène F, Lambert J, Kouatchet A, Mayaux J, Vincent F, Nyunga M, Bruneel F, Laisne L-M, Rabbat A, Lebert C, Perez P, Chaize M, Renault A, Meert A-P, Benoit D, Hamidfar R, Jourdain M, Darmon M, Schlemmer B, Chevret S, 
Lemiale V. Outcomes of Critically Ill Patients With Hematologic Malignancies: Prospective Multicenter Data From France and Belgium-A Groupe de Recherche Respiratoire en Réanimation Onco-Hématologique Study. J Clin Oncol 2013;31:2810-2818.

15. Martino R, Porras RP, Rabella N, Williams JV, Rámila E, Margall N, Labeaga R, Crowe JE, Coll P, Sierra J. Prospective Study of the Incidence, Clinical Features, and Outcome of Symptomatic Upper and Lower Respiratory Tract Infections by Respiratory Viruses in Adult Recipients of Hematopoietic Stem Cell Transplants for Hematologic Malignancies. Biol Blood Marrow Transplant 2005;11:781-796.

16. van Elden LJR, van Kraaij MGJ, Nijhuis M, Hendriksen KAW, Dekker AW, Rozenberg-Arska M, van Loon AM. Polymerase chain reaction is more sensitive than viral culture and antigen testing for the detection of respiratory viruses in adults with hematological cancer and pneumonia. Clin Infect Dis Off Publ Infect Dis Soc Am 2002;34:177-183.

17. van Kraaij MGJ, van Elden LJR, van Loon AM, Hendriksen KAW, Laterveer L, Dekker AW, Nijhuis M. Frequent detection of respiratory viruses in adult recipients of stem cell transplants with the use of real-time polymerase chain reaction, compared with viral culture. Clin Infect Dis Off Publ Infect Dis Soc Am 2005;40:662-669.

18. Schnell D, Legoff J, Mariotte E, Seguin A, Canet E, Lemiale V, Darmon M, Schlemmer B, Simon F, Azoulay É. Molecular detection of respiratory viruses in immunocopromised ICU patients: Incidence and meaning. Respir Med 2012;106:11841191.

19. Rodríguez A, Díaz E, Martín-Loeches I, Sandiumenge A, Canadell L, Díaz JJ, Figueira JC, Marques A, Alvarez-Lerma F, Vallés J, Baladín B, García-López F, Suberviola B, Zaragoza R, Trefler S, Bonastre J, Blanquer J, Rello J, H1N1 SEMICYUC Working Group. Impact of early oseltamivir treatment on outcome in critically ill patients with 2009 
pandemic influenza A. J Antimicrob Chemother 2011;66:1140-1149.

20. Choi S-M, Boudreault AA, Xie H, Englund JA, Corey L, Boeckh M. Differences in clinical outcomes after 2009 influenza A/H1N1 and seasonal influenza among hematopoietic cell transplant recipients. Blood 2011;117:5050-5056.

21. Poritz MA, Blaschke AJ, Byington CL, Meyers L, Nilsson K, Jones DE, Thatcher SA, Robbins T, Lingenfelter B, Amiott E, Herbener A, Daly J, Dobrowolski SF, Teng DH-F, Ririe KM. FilmArray, an Automated Nested Multiplex PCR System for Multi-Pathogen Detection: Development and Application to Respiratory Tract Infection. In: Costa C, editor. PLoS ONE 2011;6:e26047.

22. Ruggiero P, McMillen T, Tang Y-W, Babady NE. Evaluation of the BioFire FilmArray Respiratory Panel and the GenMark eSensor Respiratory Viral Panel on Lower Respiratory Tract Specimens. J Clin Microbiol 2014;52:288-290.

23. Gadsby NJ, Russell CD, McHugh MP, Mark H, Conway Morris A, Laurenson IF, Hill AT, Templeton KE. Comprehensive Molecular Testing for Respiratory Pathogens in Community-Acquired Pneumonia. Clin Infect Dis 2016;62:817-823.

24. Milano F, Campbell AP, Guthrie KA, Kuypers J, Englund JA, Corey L, Boeckh M. Human rhinovirus and coronavirus detection among allogeneic hematopoietic stem cell transplantation recipients. Blood 2010;115:2088-2094.

25. Self WH, Williams DJ, Zhu Y, Ampofo K, Pavia AT, Chappell JD, Hymas WC, Stockmann C, Bramley AM, Schneider E, Erdman D, Finelli L, Jain S, Edwards KM, Grijalva CG. Respiratory Viral Detection in Children and Adults: Comparing Asymptomatic Controls and Patients With Community-Acquired Pneumonia. J Infect Dis 2016;213:584591.

26. Lemiale V, Mokart D, Resche-Rigon M, Pène F, Mayaux J, Faucher E, Nyunga M, Girault C, Perez P, Guitton C, Ekpe K, Kouatchet A, Théodose I, Benoit D, Canet E, Barbier 
F, Rabbat A, Bruneel F, Vincent F, Klouche K, Loay K, Mariotte E, Bouadma L, Moreau AS, Seguin A, Meert A-P, Reignier J, Papazian L, Mehzari I, et al. Effect of Noninvasive Ventilation vs Oxygen Therapy on Mortality Among Immunocompromised Patients With Acute Respiratory Failure: A Randomized Clinical Trial. JAMA 2015;314:1711-1719.

27. Azoulay É, Schlemmer B. Diagnostic strategy in cancer patients with acute respiratory failure. Intensive Care Med 2006;32:808-822.

28. Wisdom A, Leitch ECM, Gaunt E, Harvala H, Simmonds P. Screening respiratory samples for detection of human rhinoviruses (HRVs) and enteroviruses: comprehensive VP4-VP2 typing reveals high incidence and genetic diversity of HRV species C. J Clin Microbiol 2009;47:3958-3967.

29. Wolfromm A, Porcher R, Legoff J, Peffault de Latour R, Xhaard A, de Fontbrune FS, Ribaud P, Bergeron A, Socié G, Robin M. Viral respiratory infections diagnosed by multiplex PCR after allogeneic hematopoietic stem cell transplantation: long-term incidence and outcome. Biol Blood Marrow Transplant J Am Soc Blood Marrow Transplant 2014;20:1238-1241.

30. Bosch AATM, Biesbroek G, Trzcinski K, Sanders EAM, Bogaert D. Viral and bacterial interactions in the upper respiratory tract. PLoS Pathog 2013;9:e1003057.

31. Voiriot G, Visseaux B, Cohen J, Nguyen LBL, Neuville M, Morbieu C, Burdet C, Radjou A, Lescure F-X, Smonig R, Armand-Lefèvre L, Mourvillier B, Yazdanpanah Y, Soubirou J-F, Ruckly S, Houhou-Fidouh N, Timsit J-F. Viral-bacterial coinfection affects the presentation and alters the prognosis of severe community-acquired pneumonia. Crit Care Lond Engl 2016;20:375.

32. Cawcutt K, Kalil AC. Pneumonia with bacterial and viral coinfection. Curr Opin Crit Care 2017;23:385-390.

33. McCullers JA. Insights into the interaction between influenza virus and 
pneumococcus. Clin Microbiol Rev 2006;19:571-582.

34. Jain S, Self WH, Wunderink RG, Fakhran S, Balk R, Bramley AM, Reed C, Grijalva CG, Anderson EJ, Courtney DM, Chappell JD, Qi C, Hart EM, Carroll F, Trabue C, Donnelly HK, Williams DJ, Zhu Y, Arnold SR, Ampofo K, Waterer GW, Levine M, Lindstrom S, Winchell JM, Katz JM, Erdman D, Schneider E, Hicks LA, McCullers JA, et al. Community-Acquired Pneumonia Requiring Hospitalization among U.S. Adults. $N$ Engl J Med 2015;373:415-427.

35. Van Rijn AL, Claas EC, von dem Borne PA, Kroes ACM, de Vries JJC. Rhinovirus viremia in adult patients with high viral load in bronchoalveolar lavages. J Clin Virol Off Publ Pan Am Soc Clin Virol 2017;96:105-109.

36. Lu X, Schneider E, Jain S, Bramley AM, Hymas W, Stockmann C, Ampofo K, Arnold SR, Williams DJ, Self WH, Patel A, Chappell JD, Grijalva CG, Anderson EJ, Wunderink RG, McCullers JA, Edwards KM, Pavia AT, Erdman DD. Rhinovirus Viremia in Patients Hospitalized With Community-Acquired Pneumonia. J Infect Dis 2017;216:11041111.

37. Piñana JL, Madrid S, Pérez A, Hernández-Boluda JC, Giménez E, Terol MJ, Calabuig M, Navarro D, Solano C. Epidemiologic and Clinical Characteristics of Coronavirus and Bocavirus Respiratory Infections after Allogeneic Stem Cell Transplantation: A Prospective Single-Center Study. Biol Blood Marrow Transplant J Am Soc Blood Marrow Transplant 2018;24:563-570.

38. Campbell AP, Guthrie KA, Englund JA, Farney RM, Minerich EL, Kuypers J, Corey L, Boeckh M. Clinical outcomes associated with respiratory virus detection before allogeneic hematopoietic stem cell transplant. Clin Infect Dis Off Publ Infect Dis Soc Am 2015;61:192-202.

39. Choi S-H, Huh JW, Hong S-B, Lee JY, Kim S-H, Sung H, Do K-H, Lee S-O, Kim 
M-N, Jeong J-Y, Lim C-M, Kim YS, Woo JH, Koh Y. Clinical characteristics and outcomes of severe rhinovirus-associated pneumonia identified by bronchoscopic bronchoalveolar lavage in adults: comparison with severe influenza virus-associated pneumonia. J Clin Virol Off Publ Pan Am Soc Clin Virol 2015;62:41-47.

40. Seo S, Waghmare A, Scott EM, Xie H, Kuypers JM, Hackman RC, Campbell AP, Choi S-M, Leisenring WM, Jerome KR, Englund JA, Boeckh M. Human rhinovirus detection in the lower respiratory tract of hematopoietic cell transplant recipients: association with mortality. Haematologica 2017;102:1120-1130.

41. Jacobs SE, Lamson DM, Soave R, Guzman BH, Shore TB, Ritchie EK, Zappetti D, Satlin MJ, Leonard JP, van Besien K, Schuetz AN, Jenkins SG, George KS, Walsh TJ. Clinical and molecular epidemiology of human rhinovirus infections in patients with hematologic malignancy. J Clin Virol Off Publ Pan Am Soc Clin Virol 2015;71:51-58.

42. Cox DW, Bizzintino J, Ferrari G, Khoo SK, Zhang G, Whelan S, Lee WM, Bochkov YA, Geelhoed GC, Goldblatt J, Gern JE, Laing IA, Le Souëf PN. Human rhinovirus species $\mathrm{C}$ infection in young children with acute wheeze is associated with increased acute respiratory hospital admissions. Am J Respir Crit Care Med 2013;188:1358-1364.

43. Lee W-M, Lemanske RF, Evans MD, Vang F, Pappas T, Gangnon R, Jackson DJ, Gern JE. Human rhinovirus species and season of infection determine illness severity. Am J Respir Crit Care Med 2012;186:886-891.

44. Choi S-H, Hong S-B, Kim T, Kim S-H, Huh JW, Do K-H, Lee S-O, Kim M-N, Lim C-M, Kim YS, Koh Y, Woo JH, Choi S-H, Sung H. Clinical and molecular characterization of rhinoviruses A, B, and C in adult patients with pneumonia. J Clin Virol Off Publ Pan Am Soc Clin Virol 2015;63:70-75.

45. Griggs TF, Bochkov YA, Basnet S, Pasic TR, Brockman-Schneider RA, Palmenberg AC, Gern JE. Rhinovirus C targets ciliated airway epithelial cells. Respir Res 2017;18:84. 
46. Carrat F, Leruez-Ville M, Tonnellier M, Baudel J-L, Deshayes J, Meyer P, Maury E, Galimand J, Rouzioux C, Offenstadt G. A virologic survey of patients admitted to a critical care unit for acute cardiorespiratory failure. Intensive Care Med 2006;32:156-159.

47. Hernu R, Chroboczek T, Madelaine T, Casalegno J-S, Lina B, Cour M, Argaud L, On behalf the "Flu in Lyon ICUs" Study Group. Early oseltamivir therapy improves the outcome in critically ill patients with influenza: a propensity analysis. Intensive Care Med 2018;44:257-260.

48. Kumar A. Early versus late oseltamivir treatment in severely ill patients with 2009 pandemic influenza A (H1N1): speed is life. J Antimicrob Chemother 2011;66:959-963.

49. Muthuri SG, Venkatesan S, Myles PR, Leonardi-Bee J, Al Khuwaitir TSA, Al Mamun A, Anovadiya AP, Azziz-Baumgartner E, Báez C, Bassetti M, Beovic B, Bertisch B, Bonmarin I, Booy R, Borja-Aburto VH, Burgmann H, Cao B, Carratala J, Denholm JT, Dominguez SR, Duarte PAD, Dubnov-Raz G, Echavarria M, Fanella S, Gao Z, Gérardin P, Giannella M, Gubbels S, Herberg J, et al. Effectiveness of neuraminidase inhibitors in reducing mortality in patients admitted to hospital with influenza A H1N1pdm09 virus infection: a meta-analysis of individual participant data. Lancet Respir Med 2014;2:395-404. 50. Sajjan US, Jia Y, Newcomb DC, Bentley JK, Lukacs NW, LiPuma JJ, Hershenson MB. H. influenzae potentiates airway epithelial cell responses to rhinovirus by increasing ICAM-1 and TLR3 expression. FASEB J Off Publ Fed Am Soc Exp Biol 2006;20:21212123.

51. Ogimi C, Krantz EM, Golob JL, Waghmare A, Liu C, Leisenring WM, Woodard CR, Marquis S, Kuypers JM, Jerome KR, Pergam SA, Fredricks DN, Sorror ML, Englund JA, Boeckh M. Antibiotic Exposure Prior to Respiratory Viral Infection Is Associated with Progression to Lower Respiratory Tract Disease in Allogeneic Hematopoietic Cell Transplant Recipients. Biol Blood Marrow Transplant J Am Soc Blood Marrow Transplant 
2018;doi:10.1016/j.bbmt.2018.05.016.

52. White PL, Parr C, Barnes RA. Predicting invasive aspergillosis in haematology patients by combining clinical and genetic risk factors with early diagnostic biomarkers. $J$ Clin Microbiol 2017;doi:10.1128/JCM.01122-17.

53. Wauters J, Baar I, Meersseman P, Meersseman W, Dams K, De Paep R, Lagrou K, Wilmer A, Jorens P, Hermans G. Invasive pulmonary aspergillosis is a frequent complication of critically ill H1N1 patients: a retrospective study. Intensive Care Med $2012 ; 38: 1761-1768$.

54. Martino R, Piñana JL, Parody R, Valcarcel D, Sureda A, Brunet S, Briones J, Delgado J, Sánchez F, Rabella N, Sierra J. Lower respiratory tract respiratory virus infections increase the risk of invasive aspergillosis after a reduced-intensity allogeneic hematopoietic SCT. Bone Marrow Transplant 2009;44:749-756. 


\section{FIGURE LEGENDS}

\section{Figure 1}

\section{Patient flow diagram}

* Reasons for not sampling or testing patients included weekend admissions $(n=241)$ and unusable samples $(\mathrm{n}=23)$.

Abbreviations: ARF, acute respiratory failure; ICU, intensive care unit.

Figure 2

Multivariable analysis for factors independently associated with ICU mortality among patients with ARF

Abbreviations: ICU, intensive care unit; ARF, acute respiratory failure; SOFA, Sequential Organ Failure Assessment.

\section{Figure 3}

Associations linking influenza-like virus infections or infections with other viruses to ARF and death or mechanical ventilation

Influenza-like viruses include influenza viruses, parainfluenza viruses, respiratory syncytial viruses and human metapneumovirus. Other viruses include rhinovirus and coronavirus. Abbreviations: MV, mechanical ventilation; ARF, acute respiratory failure. 


\section{Table 1}

\section{Baseline characteristics at ICU admission}

The data are numbers and percentages unless otherwise specified.

* Some patients were admitted for more than one reason.

Abbreviations: ICU, intensive care unit; IQR, interquartile range (25th and 75th quartiles) for quantitative data

\section{Table 2}

\section{Comparison of $\mathrm{ePlex}^{\circledR}$ results according to presence or absence of ARF and ICU mortality}

Categorical data are reported as numbers and percentages.

* Viral-viral and viral-bacterial co-infections were considered.

Abbreviations: ARF, acute respiratory failure; ICU, intensive care unit; HRV, human rhinovirus; EV, enterovirus; HRV-A, human rhinovirus species A; HRV-B, human rhinovirus species B; HRV-C, human rhinovirus species C; FLU, influenza virus; RSV, respiratory syncytial virus; PIV, parainfluenza virus; hMPV, human metapneumovirus

\section{Table 3}

\section{Comparison of patients with a positive versus a negative ePlex ${ }^{\circledR}$ result}

Quantitative data are reported as median [25th and 75th quartiles] and categorical data as numbers and percentages.

Abbreviations: IQR, interquartile range; HSCT, hematopoietic stem cell transplantation; ICU, intensive care unit; ARF, acute respiratory failure 


\section{Table 4}

Among patients with acute respiratory failure, comparison of patients with a positive versus a negative $\mathrm{ePlex}^{\circledR}$ result

Quantitative data are reported as median [25th and 75th quartiles] and categorical data as numbers and percentages.

Abbreviations: ARF, acute respiratory failure; IQR, interquartile range; $\mathrm{PaO}_{2} / \mathrm{FiO}_{2}$, ratio of partial pressure of arterial oxygen over fraction of inspired oxygen; SOFA, Sequential Organ Failure Assessment; CT, computed tomography; ICU, intensive care unit 


\section{Table 1}

\begin{tabular}{|c|c|c|}
\hline Variable & $\mathbf{N}$ & $\%$ \\
\hline Age, years, median [IQR] & \multicolumn{2}{|c|}{$60[49 ; 70]$} \\
\hline Male gender & 454 & 60.8 \\
\hline Chronic respiratory insufficiency & 189 & 25.3 \\
\hline Charlson comorbidity index, median [IQR] & \multicolumn{2}{|c|}{$4[3 ; 6]$} \\
\hline Poor performance status $(>2)$ & 150 & 20.1 \\
\hline \multicolumn{3}{|l|}{ Underlying malignancy } \\
\hline Lymphoid malignancy & 367 & 49.1 \\
\hline Non-Hodgkin lymphoma & 235 & 31.5 \\
\hline Chronic lymphocytic leukemia & 60 & 8 \\
\hline Acute lymphoblastic leukemia & 53 & 7.1 \\
\hline Hodgkin lymphoma & 19 & 2.5 \\
\hline Myeloid malignancy & 250 & 33.5 \\
\hline Acute myeloid leukemia & 200 & 26.8 \\
\hline Myelodysplastic syndrome & 35 & 4.7 \\
\hline Chronic myeloid leukemia & 15 & 2 \\
\hline Other & 130 & 17.4 \\
\hline Multiple myeloma & 96 & 12.8 \\
\hline Other hematological malignancy & 34 & 4.6 \\
\hline Time between diagnosis and ICU admission, days, median [IQR] & \multicolumn{2}{|c|}{$174[6 ; 865]$} \\
\hline \multicolumn{3}{|l|}{ Malignancy status at admission } \\
\hline Newly diagnosed & 280 & 37.5 \\
\hline Complete or partial remission & 174 & 23.3 \\
\hline Progression & 270 & 36.2 \\
\hline Unknown & 23 & 3 \\
\hline Hematopoietic stem cell transplantation & 190 & 25.5 \\
\hline Autologous & 84 & 11.3 \\
\hline Allogeneic & 106 & 14.2 \\
\hline Corticosteroids in the previous month & 284 & 38.2 \\
\hline Other immunosuppressants in the previous month & 136 & 18.2 \\
\hline Time from hospital to ICU admission, days, median [IQR] & \multicolumn{2}{|c|}{$4[1 ; 18]$} \\
\hline \multicolumn{3}{|l|}{ Reason for ICU admission * } \\
\hline Acute respiratory failure & 447 & 59.8 \\
\hline Shock & 316 & 42.4 \\
\hline
\end{tabular}


Table 2

\begin{tabular}{|c|c|c|c|c|c|c|c|}
\hline N (\%) & $\mathrm{N}=747$ & $\mathrm{~N}=\mathbf{4 4 7}$ & $\mathbf{N}=\mathbf{3 0 0}$ & $P$ value & $\begin{array}{c}\text { Patients who } \\
\text { died in the } \\
\text { ICU } \\
N=194\end{array}$ & $\begin{array}{c}\text { Patients alive } \\
\text { at ICU } \\
\text { discharge } \\
\quad \mathrm{N}=553\end{array}$ & $P$ value \\
\hline Positive ePlex ${ }^{(B)}$ & $163(21.8)$ & $114(25.5)$ & $49(16.3)$ & 0.004 & $56(28.9)$ & $107(19.3)$ & 0.008 \\
\hline $\mathrm{HRV} / \mathrm{EV}$ & 92 & $62(13.9)$ & $30(10)$ & 0.14 & $32(16.5)$ & $60(10.9)$ & 0.053 \\
\hline HRV-A & 35 & 22 & 13 & & 8 & 27 & \\
\hline HRV-B & 9 & 6 & 3 & & 1 & 8 & \\
\hline $\mathrm{HRV}-\mathrm{C}$ & 24 & 17 & 7 & & 11 & 13 & \\
\hline FLU-like & 54 & $48(10.7)$ & $6(2.0)$ & $<0.0001$ & $24(12.4)$ & $30(5.4)$ & 0.002 \\
\hline FLU & 20 & 20 & 0 & & 12 & 8 & \\
\hline RSV & 18 & 15 & 3 & & 7 & 11 & \\
\hline PIV & 12 & 10 & 2 & & 3 & 9 & \\
\hline HMPV & 4 & 3 & 1 & & 2 & 2 & \\
\hline Coronavirus & 22 & $11(2.5)$ & $11(3.7)$ & 0.46 & $9(4.6)$ & $13(2.4)$ & 0.17 \\
\hline Adenovirus & 5 & $2(0.5)$ & $3(1)$ & 0.65 & $1(0.5)$ & $4(0.7)$ & 1 \\
\hline hMPV & 4 & $3(0.7)$ & $1(0.3)$ & 0.91 & $2(1.0)$ & $2(0.4)$ & 0.6 \\
\hline Bocavirus & 2 & $1(0.2)$ & $1(0.3)$ & 1 & $1(0.5)$ & $1(0.2)$ & 1 \\
\hline Co-infections* & 14 & $12(2.7)$ & $2(0.7)$ & 0.086 & $11(5.7)$ & $3(0.5)$ & $<0.0001$ \\
\hline
\end{tabular}


Table 3

\begin{tabular}{|c|c|c|c|}
\hline N (\%) - median [IQR] & $\begin{array}{c}\text { Negative ePlex }^{(\mathcal{R}} \\
\mathrm{N}=584\end{array}$ & $\begin{array}{c}\text { Positive ePlex }^{\circledR} \\
\mathrm{N}=163\end{array}$ & $P$ value \\
\hline \multicolumn{4}{|l|}{ Baseline characteristics } \\
\hline Age, years & $61[49 ; 70]$ & $58[47 ; 67]$ & 0.11 \\
\hline \multicolumn{4}{|l|}{ Underlying malignancy } \\
\hline Myeloid malignancy & $209(35.8)$ & $41(25.1)$ & 0.029 \\
\hline Lymphoid malignancy & $280(47.9)$ & $87(53.4)$ & \\
\hline Other & $95(16.3)$ & $35(21.5)$ & \\
\hline \multicolumn{4}{|l|}{ Hematopoietic stem cell transplantation } \\
\hline No & $463(79.3)$ & $92(57.1)$ & $<0.0001$ \\
\hline Yes, autologous & $57(9.7)$ & $27(16.8)$ & \\
\hline Yes, allogeneic & $64(11.0)$ & $42(26.1)$ & \\
\hline Corticosteroids in the previous month & $209(36.0)$ & $75(46.0)$ & 0.026 \\
\hline $\begin{array}{l}\text { Other immunosuppressants in the previous } \\
\text { month }\end{array}$ & $97(16.6)$ & $39(23.9)$ & 0.043 \\
\hline \multicolumn{4}{|l|}{ Season at ICU admission } \\
\hline Winter & $191(32.7)$ & $72(44.2)$ & 0.035 \\
\hline Spring & $202(34.6)$ & $42(25.8)$ & \\
\hline Summer & $82(14.0)$ & $24(14.7)$ & \\
\hline Autumn & $109(18.7)$ & $25(15.3)$ & \\
\hline \multicolumn{4}{|l|}{ Reason for ICU admission } \\
\hline Acute respiratory failure & $333(57.0)$ & $114(69.9)$ & 0.004 \\
\hline Shock & $245(42.0)$ & $71(43.6)$ & 0.79 \\
\hline \multicolumn{4}{|l|}{ Respiratory symptoms on day 1} \\
\hline Respiratory symptoms with ARF & $308(52.7)$ & $111(68.1)$ & 0.0005 \\
\hline Respiratory symptoms without ARF & $114(19.5)$ & $29(17.8)$ & \\
\hline No respiratory symptoms & $162(27.8)$ & $23(14.1)$ & \\
\hline SOFA $>7$ & $229(41.5)$ & 77 (49.7) & 0.084 \\
\hline \multicolumn{4}{|l|}{ Interventions and outcomes } \\
\hline Chemotherapy & $164(28.1)$ & $31(19.0)$ & 0.025 \\
\hline \multicolumn{4}{|l|}{ Anti-infectious therapies } \\
\hline Antibacterial therapy & $452(77.9)$ & $137(84.6)$ & 0.083 \\
\hline Antifungal therapy & $224(38.4)$ & $63(38.7)$ & 1.00 \\
\hline Antiviral therapy & $241(41.3)$ & $81(49.7)$ & 0.067 \\
\hline \multicolumn{4}{|l|}{ Life-supporting interventions } \\
\hline Noninvasive ventilation & $173(29.6)$ & $65(39.9)$ & 0.017 \\
\hline Mechanical ventilation & $263(45.0)$ & $88(54.0)$ & 0.053 \\
\hline Vasoactive drugs & $284(48.6)$ & $86(52.8)$ & 0.4 \\
\hline Renal replacement therapy & $149(26.2)$ & $45(28.1)$ & 0.7 \\
\hline \multicolumn{4}{|l|}{ Outcomes } \\
\hline Hospital-acquired infection & $96(16.4)$ & $30(18.4)$ & 0.64 \\
\hline ICU mortality & $138(23.6)$ & $56(34.4)$ & 0.008 \\
\hline Hospital mortality & $210(36.0)$ & $67(41.1)$ & 0.27 \\
\hline Overall mortality on day 90 & $248(45.2)$ & $73(47.4)$ & 0.69 \\
\hline
\end{tabular}


Table 4

\begin{tabular}{|c|c|c|c|}
\hline N (\%) - median [IQR] & $\begin{array}{c}\text { Negative ePlex }^{(B)} \\
\quad \mathrm{N}=333\end{array}$ & $\begin{array}{c}\text { Positive ePlex }^{(} \\
\quad \mathrm{N}=114\end{array}$ & $P$ value \\
\hline \multicolumn{4}{|l|}{ Clinical presentation on day 1} \\
\hline Respiratory rate (/min) & $32[26 ; 38]$ & $32[26 ; 36]$ & 0.68 \\
\hline Temperature $\left({ }^{\circ} \mathrm{C}\right)$ & $38.2[37.3 ; 39.1]$ & $38.3[37.4 ; 39.2]$ & 0.31 \\
\hline Cough & $122(36.6)$ & $46(40.4)$ & 0.64 \\
\hline Purulent sputum & $34(10.4)$ & $7(6.3)$ & 0.28 \\
\hline Myalgia & $10(3.1)$ & $3(2.7)$ & 1.00 \\
\hline Rhinorrhea & $4(1.2)$ & $3(2.7)$ & 0.52 \\
\hline Chest pain & $43(13.1)$ & $8(7.2)$ & 0.13 \\
\hline Maximal oxygen flow (L/min) & $8[4 ; 15]$ & $9[4 ; 15]$ & 0.91 \\
\hline $\begin{array}{l}\mathrm{PaO}_{2} / \mathrm{FiO}_{2} \text { in patients requiring mechanical } \\
\text { ventilation }\end{array}$ & $150[96 ; 258]$ & $118[71 ; 206]$ & 0.052 \\
\hline SOFA $>7$ & 139 (44.4) & $58(52.3)$ & 0.19 \\
\hline \multicolumn{4}{|l|}{ Chest radiography pattern } \\
\hline Normal & $32(9.9)$ & $20(17.9)$ & 0.039 \\
\hline Alveolar condensations & $203(61.0)$ & $63(55.3)$ & 0.34 \\
\hline Interstitial opacities & $89(27.6)$ & $39(34.8)$ & 0.18 \\
\hline Nodular opacities & $15(4.6)$ & $1(0.9)$ & 0.13 \\
\hline Pleural effusion & $86(26.6)$ & $19(17.0)$ & 0.054 \\
\hline \multicolumn{4}{|l|}{ Computed tomography } \\
\hline Normal & $5(1.5)$ & $2(1.8)$ & 1 \\
\hline Alveolar condensations & $77(23.1)$ & $23(20.2)$ & 0.6 \\
\hline Ground-glass opacities & $53(15.9)$ & $18(15.8)$ & 1 \\
\hline Nodular patterns & $36(10.8)$ & $14(12.3)$ & 0.8 \\
\hline Pleural effusion & $82(24.8)$ & $14(12.4)$ & 0.009 \\
\hline \multicolumn{4}{|l|}{ Etiologies of pulmonary involvement } \\
\hline Infectious & & & $<0.0001$ \\
\hline Clinically documented bacterial infections & $52(15.6)$ & $9(7.9)$ & \\
\hline $\begin{array}{l}\text { Microbiologically documented bacterial } \\
\text { infections }\end{array}$ & $55(16.5)$ & $22(19.3)$ & \\
\hline \multicolumn{4}{|l|}{ Opportunistic infections } \\
\hline Invasive pulmonary aspergillosis & $13(3.9)$ & $11(9.7)$ & \\
\hline Pneumocystis jirovecii infections & $10(3)$ & $5(4.4)$ & \\
\hline \multicolumn{4}{|l|}{ Noninfectious lung involvement } \\
\hline Cardiac pulmonary edema & $39(11.7)$ & $14(12.3)$ & \\
\hline Undetermined & $48(14.4)$ & $12(10.5)$ & \\
\hline \multicolumn{4}{|l|}{ Interventions and outcomes } \\
\hline \multicolumn{4}{|l|}{ Anti-infectious therapies } \\
\hline Antibacterial therapy & $282(85.5)$ & $106(93.0)$ & 0.054 \\
\hline Antifungal therapy & $151(45.4)$ & $50(43.9)$ & 0.87 \\
\hline Antiviral therapy & $151(45.4)$ & $64(56.1)$ & 0.06 \\
\hline \multicolumn{4}{|l|}{ Life-supporting interventions } \\
\hline Noninvasive ventilation & $144(43.2)$ & $57(50)$ & 0.25 \\
\hline Mechanical ventilation & $173(52.0)$ & $67(58.8)$ & 0.25 \\
\hline Vasoactive drugs & $174(52.3)$ & $70(61.4)$ & 0.11 \\
\hline Renal replacement therapy & $78(24.2)$ & $32(28.6)$ & 0.42 \\
\hline \multicolumn{4}{|l|}{ Outcomes } \\
\hline Hospital-acquired infection & $59(17.7)$ & $21(18.4)$ & 0.98 \\
\hline ICU mortality & $81(24.3)$ & $46(40.4)$ & 0.002 \\
\hline Hospital mortality & $123(36.9)$ & $52(45.6)$ & 0.13 \\
\hline Overall mortality on day 90 & $146(46.8)$ & $55(51.4)$ & 0.48 \\
\hline
\end{tabular}


Figure 1.

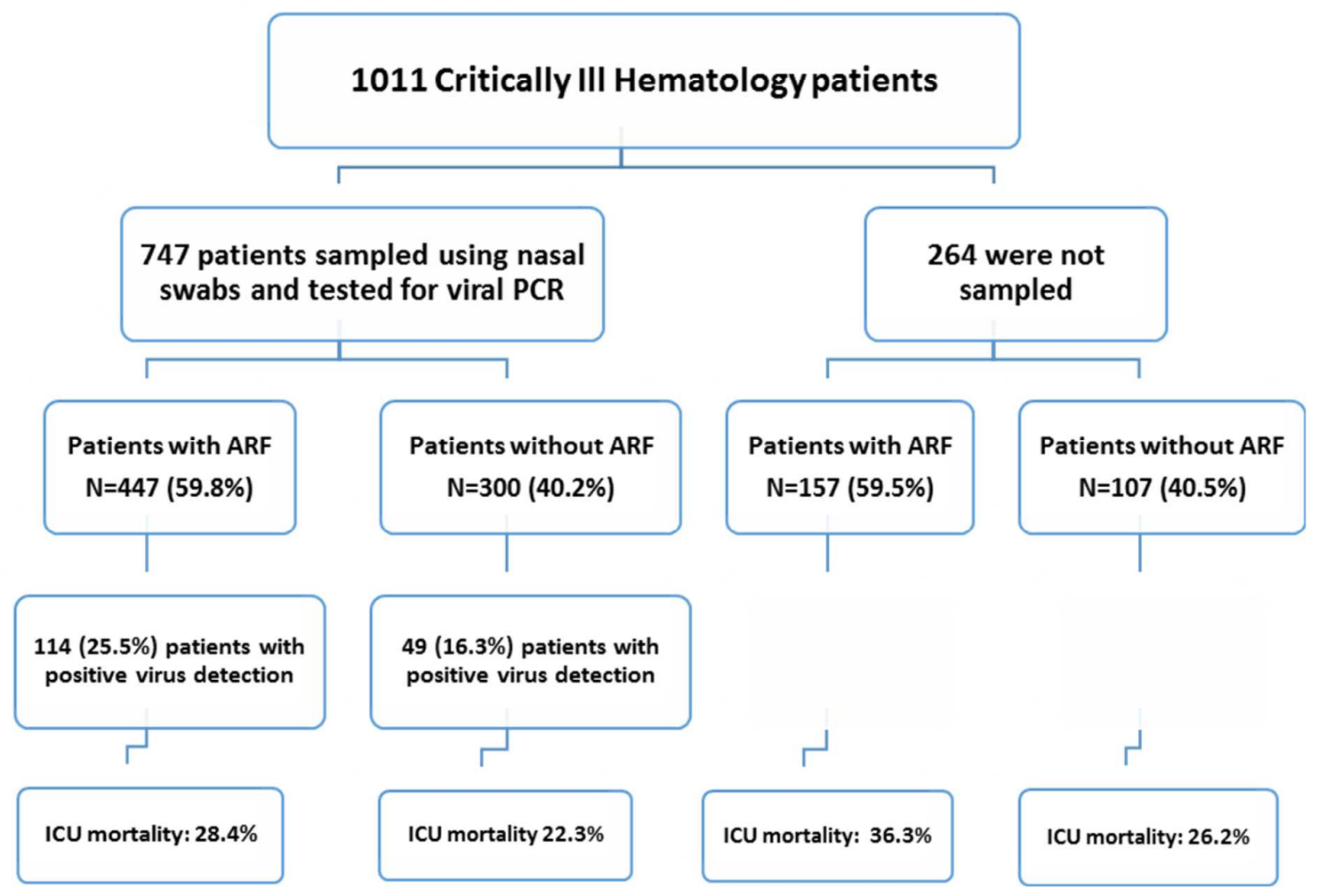


Figure 2.

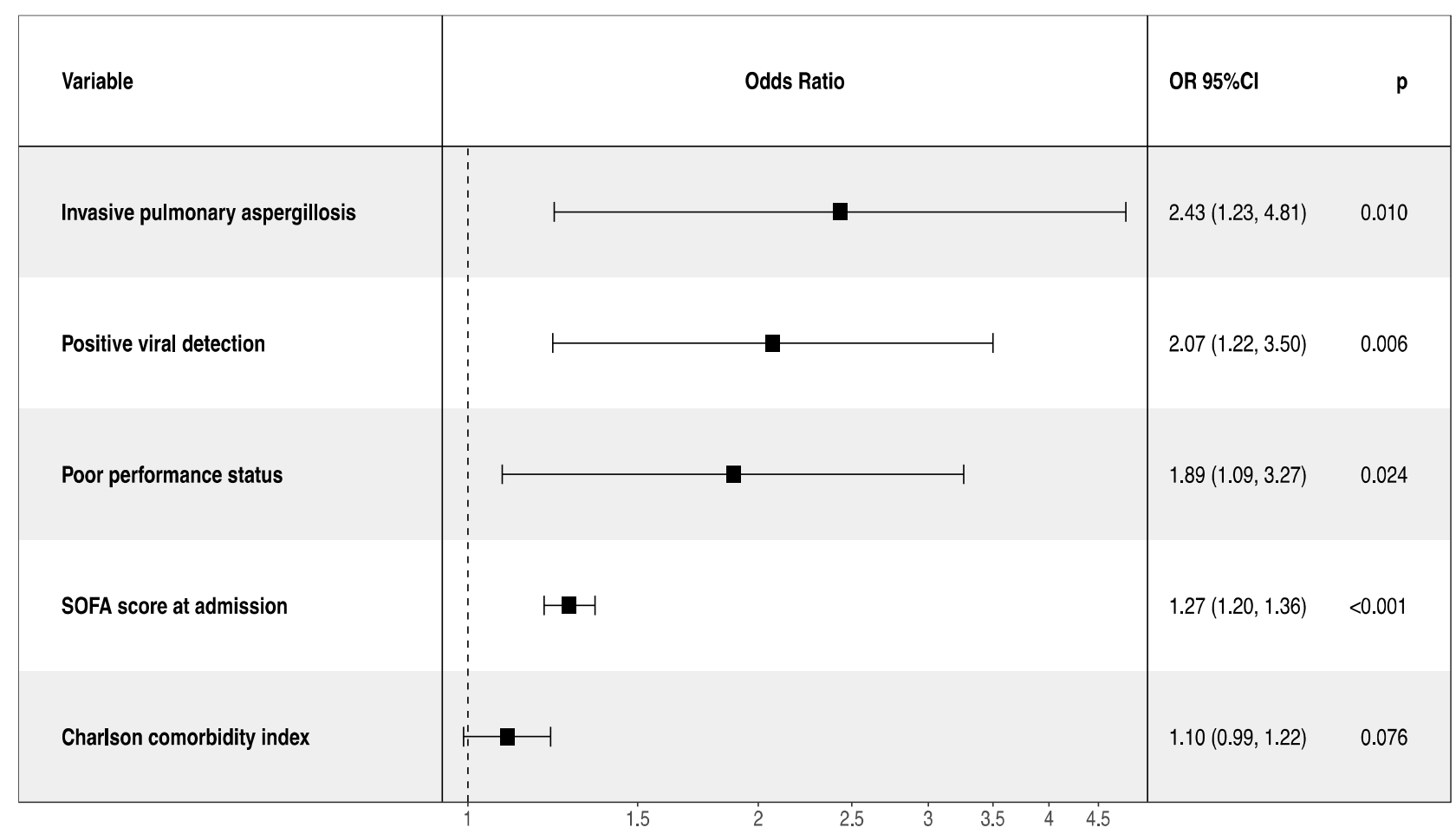


Figure 3.

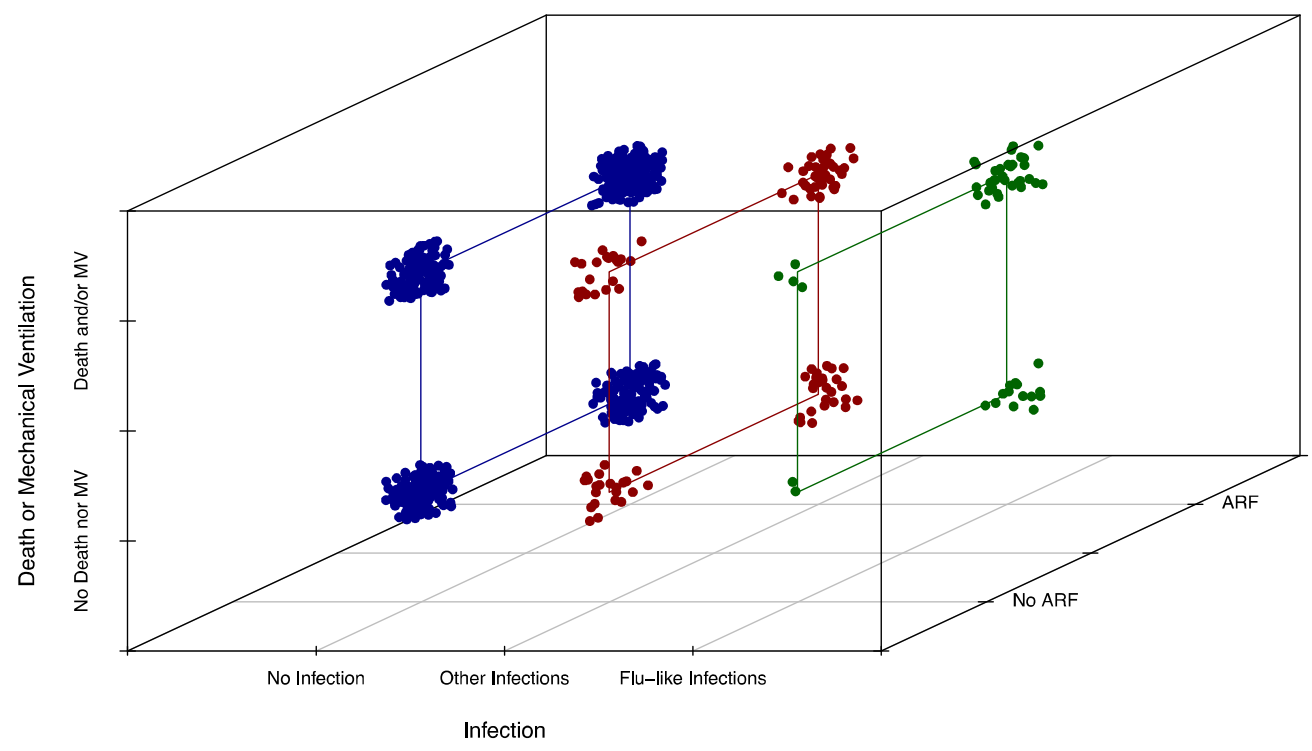




\section{Supplementary data}

\section{Clinical Significance of Upper Airway Virus Detection in Critically Ill Hematology Patients}

Jérôme Legoff ${ }^{1 *}$, Noémie Zucman ${ }^{2 *}$, Virginie Lemiale ${ }^{2}$, Djamel Mokart ${ }^{3}$, Frédéric Pène ${ }^{4}$, Jérôme Lambert $^{5}$, Achille Kouatchet ${ }^{6}$, Alexandre Demoule ${ }^{7}$, François Vincent ${ }^{8}$, Martine Nyunga ${ }^{9}$, Fabrice Bruneel $^{10}$, Adrien Contejean ${ }^{2}$, Séverine Mercier-Delarue ${ }^{1}$, Antoine Rabbat ${ }^{4}$, Christine Lebert $^{11}$, Pierre Perez $^{12}$, Anne-Pascale Meert ${ }^{13}$, Dominique Benoit ${ }^{14}$, Carole Schwebel ${ }^{15}$, Mercé Jourdain ${ }^{16}$, Michael Darmon $^{2}$, Matthieu Resche-Rigon ${ }^{5}$, Elie Azoulay ${ }^{2}$

* Jérôme LeGoff and Noémie Zucman contributed equally to this work.

${ }^{1}$ AP-HP, Virology Department, Saint Louis Teaching Hospital, Paris, FRANCE

${ }^{2}$ AP-HP, ICU, Saint Louis Teaching Hospital, Paris, FRANCE

${ }^{3}$ ICU, Paoli Calmette Institute, Marseille, FRANCE

${ }^{4}$ AP-HP, ICU, Cochin Teaching Hospital, Paris, France

${ }^{5}$ AP-HP, Statistics Department, Saint Louis Teaching Hospital, Paris, FRANCE

${ }^{6} \mathrm{ICU}$, Angers Teaching Hospital, Angers, FRANCE

${ }^{7}$ AP-HP, ICU, Pitié Salpêtrière Teaching Hospital, Paris, FRANCE

${ }^{8}$ AP-HP, ICU Avicennes Teaching Hospital, Bobigny, FRANCE

${ }^{9} \mathrm{ICU}$, Roubaix Regional Hospital Center, Roubaix, FRANCE

${ }^{10}$ ICU, Versailles Teaching Hospital, Le Chesnay, FRANCE

${ }^{11}$ ICU, District Hospital Center, La Roche sur Yon, FRANCE

${ }^{12}$ ICU, Brabois Teaching Hospital, Nancy, FRANCE

${ }^{13} \mathrm{ICU}$, Jules Bordet Institute, Brussels, BELGIUM

${ }^{14}$ ICU, Ghent University Hospital, Ghent, BELGIUM

${ }^{15}$ ICU, Grenoble Teaching Hospital, Grenoble, FRANCE

${ }^{16} \mathrm{ICU}$, Regional Teaching Hospital, Lille, FRANCE

Corresponding author: Elie Azoulay, Medical Intensive Care Unit, Hôpital Saint-Louis, 1 avenue Claude Vellefaux, 75010 Paris, FRANCE

E-mail: elie.azoulay@aphp.fr 


\section{Methods}

Step wise model.

In the step wise model, we considered variables already known as prognostic factors in the princeps study based on this cohort (Azoulay, E., Mokart, D., Pène, F., Lambert, J., Kouatchet, A., Mayaux, J., Vincent, F., Nyunga, M., Bruneel, F., Laisne, L.M. and Rabbat, A., 2013. Outcomes of critically ill patients with hematologic malignancies: prospective multicenter data from France and Belgium-a groupe de recherche respiratoire en reanimation onco-hematologique study. Journal of Clinical Oncology, 31(22), pp.2810-2818). In practice we considered the following factors: poor ECOG performance status (Performance status), Charlson comorbidity index (Charlson), allogeneic hematopoietic stem cell transplant [HSCT] recipient (Allograft), complete or partial remission (Remission), time from hospital to ICU admission $<24 \mathrm{~h}$ (Time to ICU $<24 \mathrm{~h}$ ), SOFA score (SOFA), organ infiltration by the malignancy (Organ infiltration), and invasive pulmonary aspergillosis (Aspergillus). Admission after cardiac arrest was not considered due to the too small number of patients with admission after cardiac arrest in this subcohort. Underlying malignancies was added in initial model as immunocompromised patients are more susceptible for severe viral infection (Underlying malignancies). Nevertheless, this variable was not kept by the variable selection procedure. Variable selection was a backward stepwise procedure (backward and forward) with a stopping rule based on the Akaike criterion. Please find the complete procedure below, that we have added in supplementary data. 
The linear predictor considered for the initial logistic model was the following:

ICU death Underlying malignancies + Performance status + Charlson + Allograft + Remission + Time to ICU $<24 \mathrm{~h}+$ SOFA + Organ infiltration + Aspergillus + Viral detection

The complete selection process is described below. For all model the Akaike Criteria (AIC) is given:

Start: $\mathrm{AIC}=420.19$

ICU death Underlying malignancies + Performance status + Charlson + Allograft + Remission + Time to ICU $<24 \mathrm{~h}+$ SOFA + Organ infiltration + Aspergillus + Viral detection

$\begin{array}{llll} & \text { Df } & \text { Deviance } & \text { AIC } \\ \text { - Underlying malignancies } & 2 & 398.13 & 418.13 \\ \text { - Allograft } & 1 & 396.20 & 418.20 \\ \text { - Organ infiltration } & 1 & 396.32 & 418.32 \\ \text { - Time to ICU <24h } & 1 & 396.41 & 418.41 \\ \text { - Remission } & 1 & 396.96 & 418.96 \\ \text {-none> } & & 396.19 & 420.19 \\ \text { - Charlson } & 1 & 398.73 & 420.73 \\ \text { - Performance status } & 1 & 399.37 & 421.37 \\ \text { - Aspergillus } & 1 & 401.12 & 423.12 \\ \text { - Viral detection } & 1 & 402.08 & 424.08 \\ \text { - SofA } & 1 & 471.05 & 493.05\end{array}$

Step: $\mathrm{AIC}=418.13$

ICU death $~$ Performance status + Charlson + Allograft + Remission + Time to ICU $<24 \mathrm{~h}+$ SOFA + Organ infiltration + Aspergillus + Viral detection

- Allograft

Df Deviance AIC

- Organ infiltration

$1 \quad 398.19 \quad 416.19$

- Time to ICU $<24 h$

$\begin{array}{lll}1 & 398.34 & 416.34\end{array}$

- Remission

$1 \quad 398.36 \quad 416.36$

$<$ none>

$1 \quad 398.60 \quad 416.60$

- Charlson

- Performance status

398.13

418.13

- Aspergillus

- Viral detection

401.20

419.20

1

$1 \quad 401.42$

419.42

1403.12

421.12

- SOFA

$1 \quad 403.92$

421.92

$1 \quad 472.52$

490.52

Step: $\mathrm{AIC}=416.19$ 


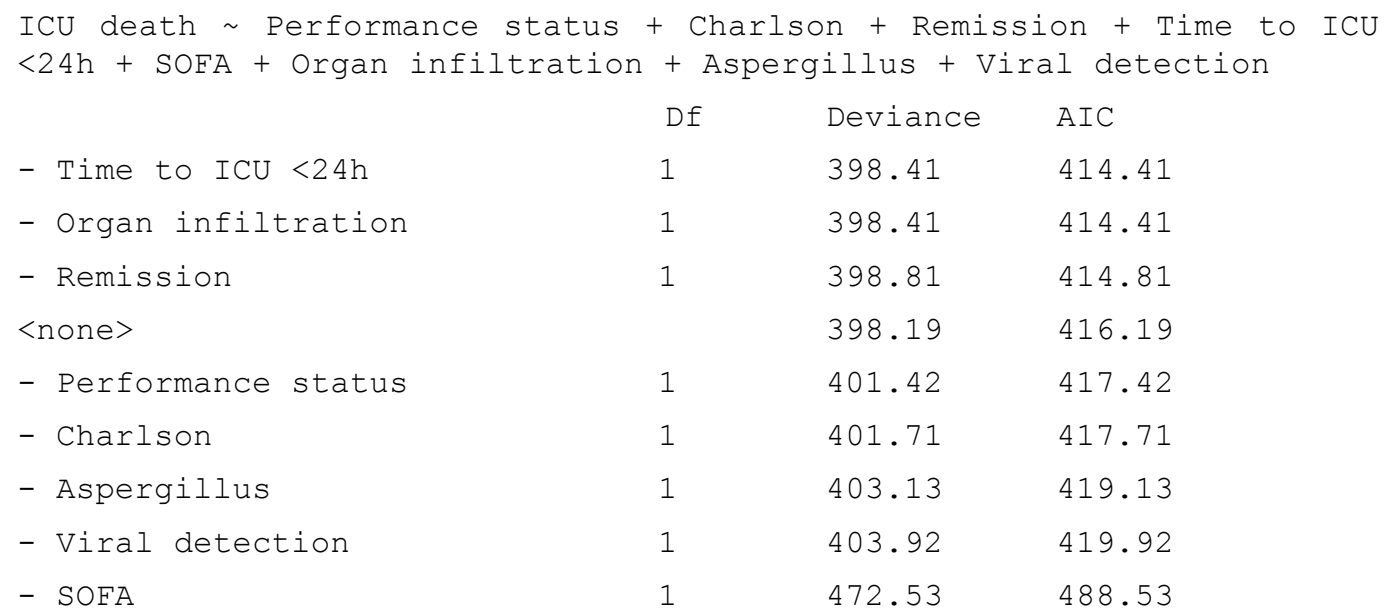

Step: $\mathrm{AIC}=414.41$

ICU death Performance status + Charlson + Remission + SOFA + Organ infiltration + Aspergillus + Viral detection

$\begin{array}{lccc} & \text { Df } & \text { Deviance } & \text { AIC } \\ \text { - Organ infiltration } & 1 & 398.59 & 412.59 \\ \text { - Remission } & 1 & 399.05 & 413.05 \\ \text { <none> } & & 398.41 & 414.41 \\ \text { - Charlson } & 1 & 401.79 & 415.79 \\ \text { - Performance status } & 1 & 401.92 & 415.92 \\ \text { - Aspergillus } & 1 & 403.44 & 417.44 \\ \text { - Viral detection } & 1 & 404.02 & 418.02 \\ \text { - SOFA } & 1 & 472.61 & 486.61\end{array}$

\section{Step: $\mathrm{AIC}=412.59$}

Icu death Performance status + Charlson + Remission + SOFA + Aspergillus + Viral detection

$\begin{array}{lccc} & \text { Df } & \text { Deviance } & \text { AIC } \\ \text { - Remission } & 1 & 399.27 & 411.27 \\ \text { <none> } & & 398.59 & 412.59 \\ \text { - Charlson } & 1 & 401.98 & 413.98 \\ \text { - Performance status } & 1 & 402.06 & 414.06 \\ \text { - Aspergillus } & 1 & 403.50 & 415.50 \\ \text { - Viral detection } & 1 & 404.09 & 416.09 \\ \text { - SOFA } & 1 & 472.69 & 484.69\end{array}$

Step: $\mathrm{AIC}=411.27$

Icu death Performance status + Charlson + SOFA + Aspergillus + Viral detection

$\begin{array}{llll} & \text { Df } & \text { Deviance } & \text { AIC } \\ \text { <none> } & & 399.27 & 411.27 \\ \text { - Performance status } & 1 & 402.75 & 412.75\end{array}$




$\begin{array}{llll}\text { - Charlson } & 1 & 402.98 & 412.98 \\ \text { - Viral detection } & 1 & 404.26 & 414.26 \\ \text { - Aspergillus } & 1 & 404.43 & 414.43 \\ \text { - SOFA } & 1 & 473.71 & 483.71\end{array}$

$\begin{array}{lc}\text { The coefficient obtained with the final model is: } \\ \text { Coefficients: } & -3.7521 \\ \text { (Intercept) } & 0.5387 \\ \text { Performance status } & 0.1040 \\ \text { Charlson } & 0.2411 \\ \text { SofA } & 0.8552 \\ \text { Aspergillus } & 0.6199 \\ \text { Viral detection Pos } & 504.4 \\ \text { Degrees of Freedom: } 419 \text { Total (i.e. Null); } 414 \text { Residual } \\ \text { Null Deviance: } & \text { AIC: } 411.3 \\ \text { Residual Deviance: } 399.3 & \end{array}$




\section{Results}

Table S1. Frequencies of Influenza virus, Respiratory Syncitial Virus, and Rhinovirus according to the season.

\begin{tabular}{lcc}
\cline { 2 - 3 } & \multicolumn{2}{c}{ Influenza } \\
\cline { 2 - 3 } Winter & 247 & 16 \\
\cline { 2 - 3 } Neg & Pos \\
\hline Spring & 241 & 3 \\
\hline Summer & 106 & 0 \\
\hline Autumn $^{*}$ & 133 & 1 \\
\hline p value $^{a}$ & & 0.0007 \\
\hline
\end{tabular}

\begin{tabular}{cc}
\hline \multicolumn{2}{c}{ RSV } \\
\hline Neg & Pos \\
\hline 247 & 16 \\
\hline 243 & 1 \\
\hline 106 & 0 \\
\hline 133 & 1 \\
\hline & $<0.0001$ \\
\hline
\end{tabular}

\begin{tabular}{cc}
\hline \multicolumn{2}{c}{ Rhinovirus } \\
\hline Neg & Pos \\
\hline 234 & 29 \\
\hline 223 & 21 \\
\hline 86 & 20 \\
\hline 112 & 22 \\
\hline & 0.02 \\
\hline
\end{tabular}

${ }^{\mathrm{a}}$ Fisher exact test

Table S2. Pathogens detected by ePlex in in patients with no respiratory.

\begin{tabular}{|l|l|}
\hline Pathogen & $\begin{array}{l}\text { Number of } \\
\text { positive samples }\end{array}$ \\
\hline Adenovirus & 1 \\
\hline Adenovirus-CoronavirusOC43 & 1 \\
\hline Coronavirus229E & 4 \\
\hline CoronavirusHKU1 & 1 \\
\hline CoronavirusNL63 & 1 \\
\hline CoronavirusOC43 & 1 \\
\hline CoronavirusOC43-Rhinovirus & 1 \\
\hline Legionnella pneumophila-CornavirusOC43-Rhinovirus & 1 \\
\hline Rhinovirus & 12 \\
\hline
\end{tabular}

Table S3. ICU mortality in patients with no respiratory symptoms with a positive ePlex result or a negative ePlex result.

\begin{tabular}{lcc}
\multirow{2}{*}{ ICU mortality } & ePlex negative & ePlex positive \\
\cline { 2 - 3 } No & 131 & 19 \\
\hline Yes & 31 & 4 \\
\hline${ }^{p}$ value $^{a}$ & 1 & \\
\hline \multicolumn{2}{c}{${ }^{\mathrm{a}}$ Fisher exact test }
\end{tabular}


Table S4. Multivariable analysis for factors independently associated with ICU mortality among all patients admitted to ICU with a ePlex test.

\begin{tabular}{lcccc}
\hline & OR & $\begin{array}{l}\text { CI95 } \\
\text { Low }\end{array}$ & $\begin{array}{l}\text { CI95 } \\
\text { High }\end{array}$ & P.value \\
\hline Invasive pulmonary aspergillosis & 2.36 & 1.23 & 4.51 & 0.0094 \\
\hline Positive Eplex & 1.64 & 1.06 & 2.54 & 0.026 \\
\hline Poor performance status & 2.30 & 1.50 & 3.53 & 0.00014 \\
\hline SOFA score at admission & 1.28 & 1.22 & 1.34 & $3.20-23$ \\
\hline Charlson comorbidity index & 1.14 & 1.05 & 1.24 & 0.0015 \\
\hline
\end{tabular}

Table S5. Impact of steroid therapy during ICU stay in patients with ARF. Multivariable analysis for factors independently associated with ICU mortality among patients with ARF. When adjusted on factors associated with mortality, steroid therapy was not significantly associated with a worse prognosis.

\begin{tabular}{lllll}
\hline & OR & CI95 & CI95 & P.value \\
& & low & high & \\
\hline Invasive pulmonary aspergillosis & 2.42 & 1.23 & 4.79 & 0.011 \\
\hline Positive Eplex & 2.05 & 1.21 & 3.48 & 0.0075 \\
\hline Poor performance status & 1.85 & $\mathbf{1 . 0 6}$ & 3.22 & 0.029 \\
\hline SOFA score at admission & 1.28 & $\mathbf{1 . 2 0}$ & $\mathbf{1 . 3 6}$ & $\mathbf{6 . 2 0 - 1 5}$ \\
\hline Charlson comorbidity index & $\mathbf{1 . 1 0}$ & $\mathbf{0 . 9 9}$ & $\mathbf{1 . 2 2}$ & $\mathbf{0 . 0 7 2}$ \\
\hline Steroid therapy during ICU stay & $\mathbf{1 . 3 2}$ & $\mathbf{0 . 8 1}$ & $\mathbf{2 . 1 5}$ & $\mathbf{0 . 2 7}$ \\
\hline
\end{tabular}

\section{Table S6.}

Impact of steroid therapy during ICU stay in patients with ARF and a positive viral detection. Multivariable analysis for factors independently associated with ICU mortality among patients with ARF. When adjusted on factors associated with mortality, steroid therapy was not significantly associated with a worse prognosis.

\begin{tabular}{lcccc}
\hline & OR & $\begin{array}{l}\text { CI95 } \\
\text { low }\end{array}$ & $\begin{array}{l}\text { CI95 } \\
\text { high }\end{array}$ & p.value \\
\hline Invasive pulmonary aspergillosis & 7.66 & 2.15 & 33.34 & 0.0031 \\
\hline Poor performance status & 1.43 & 0.52 & 3.91 & 0.48 \\
\hline SOFA score at admission & 1.32 & 1.17 & 1.52 & $3.3 e-05$ \\
\hline Charlson comorbidity index & $\mathbf{1 . 0 4}$ & 0.85 & $\mathbf{1 . 2 9}$ & 0.69 \\
\hline Steroid therapy during ICU stay & $\mathbf{1 . 0 3}$ & $\mathbf{0 . 4 1}$ & $\mathbf{2 . 6 3}$ & $\mathbf{0 . 9 5}$ \\
\hline
\end{tabular}


Figure S1. Daily SOFA score according to the detection of any respiratory virus (A) or of influenza, parainfluenza, and respiratory syncytial viruses (B).

Abbreviations: SOFA, Sequential Organ Failure Assessment; PIV, parainfluenza virus; RSV, respiratory syncytial virus; D, day

A.

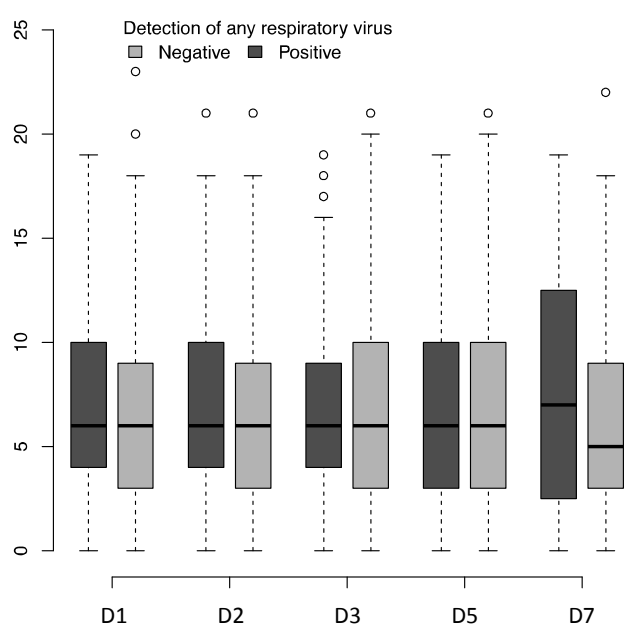

B.

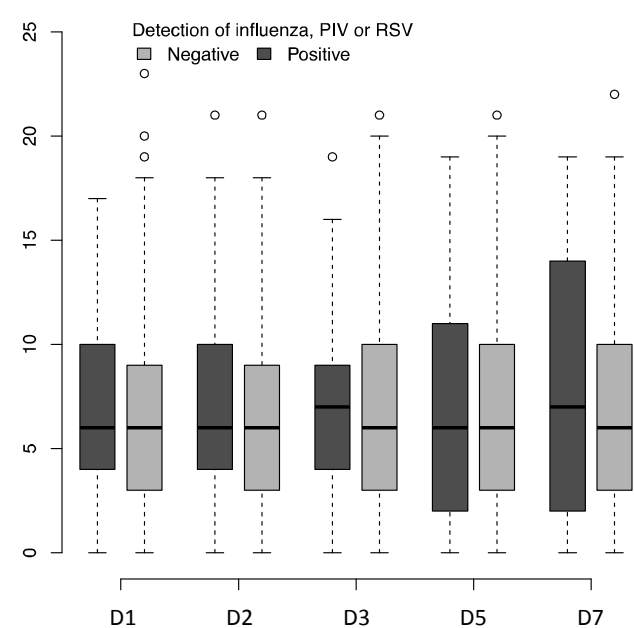

